\title{
Hydrometallurgical Recovery of Nano-Palladium from Spent Catalyst
}

\author{
M.A. Barakat ${ }^{1, *}$, G.A. EL-Mahdy ${ }^{2}$, M. Hegazy ${ }^{2}$ and F. Zahran ${ }^{2}$ \\ ${ }^{1}$ Central Metallurgical R \& D Institute, P.O. Box 87, Helwan 11421, Cairo, Egypt \\ ${ }^{2}$ Department of Chemistry, Faculty of Science, Helwan University, Helwan 11421, Cairo, Egypt
}

\begin{abstract}
Hydrometallurgical recovery of nano-palladium (Pd) from spent $\mathrm{Pd} / \mathrm{Al}_{2} \mathrm{O}_{3}$ catalyst has been investigated. The Pd content in the spent catalyst sample was assayed to be $0.42 \%$ while the remainder was mainly aluminum oxide. Mixture of $\mathrm{HCl}$ and $\mathrm{AlCl}_{3}$ was studied as leaching agent for the sample. The Pd was deposited with formic acid. Different parameters affecting leaching and deposition processes such as, time, temperature, liquid/solid ratio, were investigated. Phase of spent catalyst were identified by X-ray diffraction (XRD) analysis. The deposited Pd was characterized by scanning electron microscope (SEM), transmission electron microscope (TEM) and energy dispersive X-ray (EDX) for identification of the grain size and composition. The deposited palladium was found to be in the nano-size range $(34.5-70.5 \mathrm{~nm})$.
\end{abstract}

Key Words: Spent catalyst, palladium, leaching, recovery, electroless deposition.

\section{INTRODUCTION}

Palladium $(\mathrm{Pd})$ is a well-known precious metal playing important role in many industrial applications such as: jewellery and ornaments, electronics, telephone circuits, heat and corrosion resistance apparatus, catalysts and dental alloys [1-5]. Due to its low natural abundance, high price and its increasing demands in various ordinary and technologically advanced fields of industry, the trend is to recover and refine Pd from various spent materials [6-11]. The palladium metal catalyst is usually consisted of a metal coat supported on $\gamma$-alumina, which is frequently used as a carrier (supported layer) for the Pd. Spent catalyst is a hazardous waste, which can be produced from the periodic disposal of poisoned catalyst, or from the loss of catalyst due to entrainment [12]. The efficient recovery and purification of palladium from spent catalyst is economically desired. Hydrometallurgical treatment is a common technique for the recovery and separation of precious metals from spent catalysts. These techniques are usually carried out by two different ways; support dissolution and precious metal dissolution [13-15]. In the first technique, the supported layer is dissolved with a non-oxidizing acid or base while the precious metals are not dissolved and remain as sludge. However, this process requires a large amount of reagents. In the second one, the precious metals are extracted from the supported layer by an acidic dissolution with an oxidant, leaving the bulk of the support unaffected. Most of the other techniques used for the dissolution of precious metals are based on aggressive reagents, and, sometimes high pressure leaching, which are environmentally unsafe, highly corrosive and costly. Unlike platinum group metals, Pd can be brought

*Address correspondence to this author at the Central Metallurgical R \& D Institute, P.O. Box 87, Helwan 11421, Cairo, Egypt; Tel: +20 25010642; Fax: +20 25010639 E-mail: mabarakat@gmail.com somewhat easily into solution. Different leaching mixtures [4,13-19] such as $\mathrm{HCl}, \mathrm{H}_{2} \mathrm{SO}_{4}$, or chloride salt, e.g., $\mathrm{NaCl}$ in the presence of oxidizing agent, e.g., $\mathrm{HNO}_{3}, \mathrm{Br}_{2}$ or $\mathrm{Cl}_{2}$ have been used as leachants for Pd. However, most of theses leachants cause environmental pollution. Despite the highly efficient and ease Pd dissolution in concentrated nitric acid, this method is not favorable due to the high cost of the acid and the evolution of hazardous nitric oxides. In addition, the highly oxidizing nature of the remained nitric acid will prevent Pd reduction. Thus, an alternative leaching process is necessary for Pd recovery. Separation process of Pd from solution was carried out by electroless deposition and electrodeposition techniques. In the electroless deposition technique, $\mathrm{Pd}$ is reduced from the solution using formalin, formic acid, aluminum powder, zinc powder, stannous chloride, hydrazine, ethylene glycol, or through bioreduction [11, 20-28] with Pd been deposited in spongy form. In the electrodeposition technique, $\mathrm{Pd}$ is deposited with smaller grain size and higher purity than during electroless deposition [29-34]. However, the electrodeposition techniques are usually expensive. The aim of this work is to recover and separate pure $\mathrm{Pd}$ from spent $\mathrm{Pd} / \mathrm{Al}_{2} \mathrm{O}_{3}$ catalyst utilizing a clean, economic and simple technique. A mixture of dilute hydrochloric acid and aluminum chloride was investigated for achieving the optimum recovery of Pd. Formic acid precipitation was used to separate Pd from the leaching liquor.

\section{EXPERIMENTAL}

\subsection{Materials}

A homogenous sample of spent $\mathrm{Pd} / \mathrm{Al}_{2} \mathrm{O}_{3}$ catalyst was provided by Kima Co. Fertilizers, Aswan, Egypt. The original catalyst was used for de-oxygenation during hydrogen production. The spent catalyst was in the form of cylindrical pellets of alumina coated with a thin layer of palladium. The pellets have a diameter of $2 \mathrm{~mm}$ and a length of $3 \mathrm{~mm}$. 


\subsection{Chemicals}

Palladium chloride (5 wt \%) was used as a source for pure palladium. Hydrochloric acid (34\%) and aluminum chloride $(98 \%)$ were used for the preparation of leaching solutions. Dimethyl glycoxime $(99.99 \%)$ was used for palladium determination. $1 \mathrm{M}$ sodium hydroxide solution was used for $\mathrm{pH}$ adjustment. All used chemicals were of high grade for laboratory use. Double-distilled water was used for dilutions.

\subsection{Recovery and Separation of Palladium}

Preliminary experiments showed that contact time during the leaching process is important for efficient recovery of palladium. Therefore, $0.5 \mathrm{~g}$ of spent catalyst was leached with different reagent combinations in a $60 \mathrm{ml}$ conical flask fitted well and immersed in a thermostatic shaker water bath model (DUBNOFF BATH BSD/D). In the end of each experiment, the solution was filtered off and analyzed for $\mathrm{Pd}$ content determination, from which the recovery of $\mathrm{Pd}$ was calculated. A stock solution containing Pd was prepared from the spent catalyst at the optimum leaching conditions and used for Pd separation experiments. In this case, $10 \mathrm{ml}$ aliquots of the leach solution was mixed with different mixtures of dilute hydrochloric acid and aluminum chloride in a $60 \mathrm{ml}$ conical flask. The solution was heated and filtered off. The produced $\mathrm{Pd}$ solutions were analyzed to calculate the percent recovery of palladium.

\subsection{Assay Methods}

The phase of the spent catalyst was identified by XRD analysis. The spent catalyst sample and Pd deposits were subjected to energy dispersive X-ray (EDX) analysis. The Pd deposits were gold-coated by fine coater (Jeol JSC-1200) for characterization of grain sizes and morphologies by scanning electron microscope (Jeol JSM-5410). The grain size of the deposited $\mathrm{Pd}$ was evaluated by transmission electron microscope (Ziess 10/A).

\section{RESULTS AND DISCUSSION}

\subsection{Extraction of Palladium}

\subsubsection{Effect of the Hydrochloric Acid Concentration on the Efficiency of Pd Recovery}

One gram of spent catalyst sample was subjected to $\mathrm{X}$ - ray analysis with Philips X-ray diffractometer model PW/1710 with Ni-filter, Cu-radiation $\left(=1.542 \mathrm{~A}^{\circ}\right)$ at $40 \mathrm{kV}$, $30 \mathrm{~mA}$ and scanning speed $0.02 \mathrm{8} / \mathrm{s}$. The diffraction charts and relative intensities were obtained and compared with JCPDS files. Fig. (1) shows the XRD-pattern of the spent catalyst sample. It can be seen that the sample constituents are mainly boehmite, $\gamma-\mathrm{Al}_{2} \mathrm{O}_{3}$ and gibbsite, with minor $\mathrm{Pd}$ quantity. Palladium can form stable chloro-complexes such as $\mathrm{PdCl}^{+}, \mathrm{PdCl}_{2}, \mathrm{PdCl}_{3}, \mathrm{PdCl}_{4}{ }^{-2}$ in acidic chloride solutions [11]. At about $0.1 \mathrm{M} \mathrm{Cl}^{-}$and higher, the predominant species in solution is $\mathrm{PdCl}_{4}{ }^{-2}$. The formation of this complex in solution enhances the dissolution of $\mathrm{Pd}$ from the containing materials, as it is explained below. Palladium can be oxidized with a standard electrode potential $0.62 \mathrm{~V}$ in the presence of chloride ions [35-37] according to the reaction:

$$
\mathrm{Pd}+4 \mathrm{Cl}^{-} \longrightarrow\left[\mathrm{PdCl}_{4}\right]^{2-}+2 \mathrm{e}^{-}, \mathrm{E}^{\circ}=0.62 \mathrm{~V}
$$

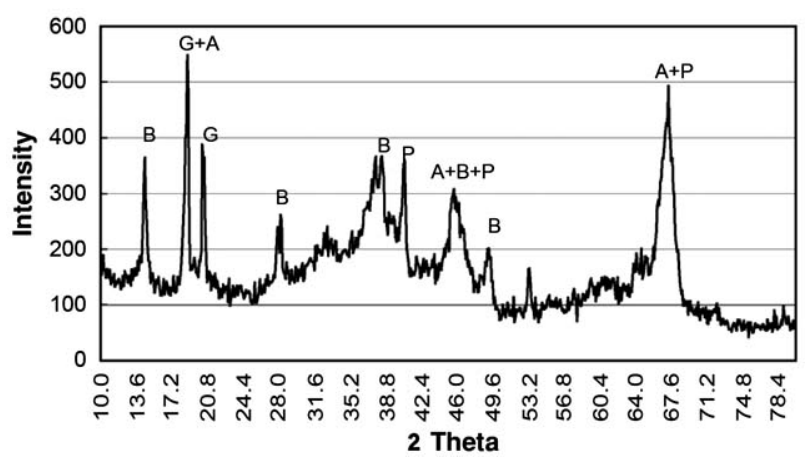

Fig. (1). The XRD pattern of the spent catalyst sample before leaching [11]. $\mathrm{B}=$ boehmite (syn.- $\mathrm{AlOOH}$ ), $\mathrm{A}=\gamma-\mathrm{Al}_{2} \mathrm{O}_{3}, \mathrm{G}=$ gibbsite $\mathrm{Al}(\mathrm{OH})_{3}, \mathrm{P}=$ palladium.

$\mathrm{HCl} / \mathrm{AlCl}_{3}$ acid salt mixture promotes the dissolution of $\mathrm{Pd}$ and decreases somewhat the problem arised from using aqua regia by elimination the losses of reactant through volatilization. $\mathrm{AlCl}_{3}$ dissolved in water to give $\mathrm{AlOCl}$ and $\mathrm{HCl}$. The aluminum hypochlorite acts as a supplier for the free oxygen atoms. These atoms along with the chloride ions dissolve Pd:

$$
\mathrm{AlCl}_{3}+\mathrm{H}_{2} \mathrm{O} \longrightarrow \mathrm{AlOCl}+2 \mathrm{HCl}
$$

Accordingly, palladium leaching with aluminum chloride in hydrochloric acid was studied to optimize the different parameters that control dissolution process. Figs. (2-a and 2b) showed the EDX pattern of the Pd spent catalyst before and after leaching, respectively. It can be seen that the $\mathrm{Pd}$ peak disappeared (Fig. 2-b), which proves the complete extraction of palladium from the spent catalyst.

The effect of hydrochloric acid concentration (from 0 to $20 \%$ ) on palladium dissolution from the spent catalyst in the absence and presence of aluminum chloride, at liquid: solid ratio $(\mathrm{L} / \mathrm{S})$ of 20 was studied. The results are shown in (Fig. 3). Leaching conditions were maintained at $80{ }^{\circ} \mathrm{C}$ for 2 $\mathrm{h}$, In the absence of $\mathrm{AlCl}_{3}$, palladium extraction was gradually increased with increasing hydrochloric acid concentration, reaching a steady state value of $81.85 \%$ at $10 \% \mathrm{HCl}$. For solutions of the latter acid concentration value in the presence of $\mathrm{AlCl}_{3}, \mathrm{Pd}$ extraction increased up to $91.3 \%$ with $2.5 \% \mathrm{AlCl}_{3}$. A complete dissolution for $\mathrm{Pd}$ was achieved with both of $5 \%$ and $7.5 \% \mathrm{AlCl}_{3}$. When $\mathrm{Pd}$ catalyst is stored in the atmosphere, its surface is covered with adsorbed oxygen. The unusual dissolution of $\mathrm{Pd}$ in hydrochloric acid in the absence of $\mathrm{AlCl}_{3}$ is attributed to the oxidizing effect of the adsorbed oxygen that is formed on the Pd surface as follows [38]:

$$
\mathrm{Pd}+\mathrm{O}_{\mathrm{ads}}+4 \mathrm{Cl}^{-}+2 \mathrm{H}^{+} \longrightarrow\left[\mathrm{PdCl}_{4}\right]^{2-}+\mathrm{H}_{2} \mathrm{O}
$$

Further, Pd present as a thin metallic layer on the support pellets with a large surface area that favors its attack by hydrochloric acid.

\subsubsection{Effect of Temperature on the Recovery of Pd}

Palladium recovery from the spent catalyst was studied as a function of time in a wide temperature range (from 20 to $80{ }^{\circ} \mathrm{C}$ ) with $10 \% \mathrm{HCl}, 5 \% \mathrm{AlCl}_{3}$, and $\mathrm{L} / \mathrm{S}$ ratio of 20 . The results are shown in Fig. (4). It can be seen that, $\mathrm{Pd}$ 


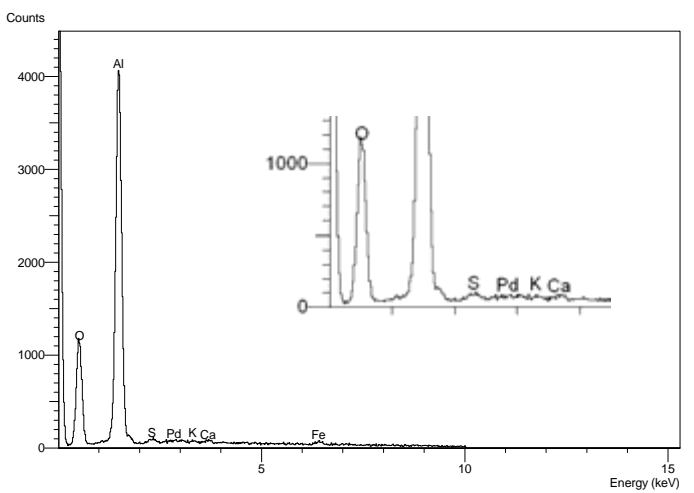

a)

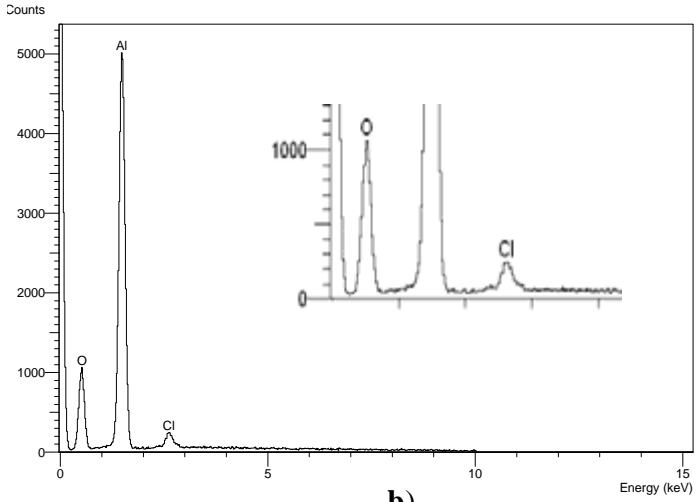

b)

Fig. (2) The XRD pattern of the spent catalyst sample. a) Before leaching (oxygen, aluminum, sulfur, potassium, calcium, and palladium). b) After leaching (oxygen, aluminum, and chlorine).

extraction continuously rises with time and under the investigated temperature $\left(20\right.$ to $\left.80{ }^{\circ} \mathrm{C}\right)$. The results indicated that at low temperature range $\left(20\right.$ to $\left.40{ }^{\circ} \mathrm{C}\right)$, Pd recovery gradually increased attaining $50.97 \%$ and $75.1 \%$ after $2 \mathrm{~h}$, respectively. However, at higher temperature range (60 to 80 ${ }^{\circ} \mathrm{C}$ ), the Pd recovery fast increased early (during the first 30 $\mathrm{min}$ ) and then gradually increased till attaining a maximum recovery value of $100 \%$ after $2 \mathrm{~h}$. Palladium recovery profiles at leaching temperatures of 60 and $80{ }^{\circ} \mathrm{C}$ are superimposed and the next experiments were held at $60{ }^{\circ} \mathrm{C}$.

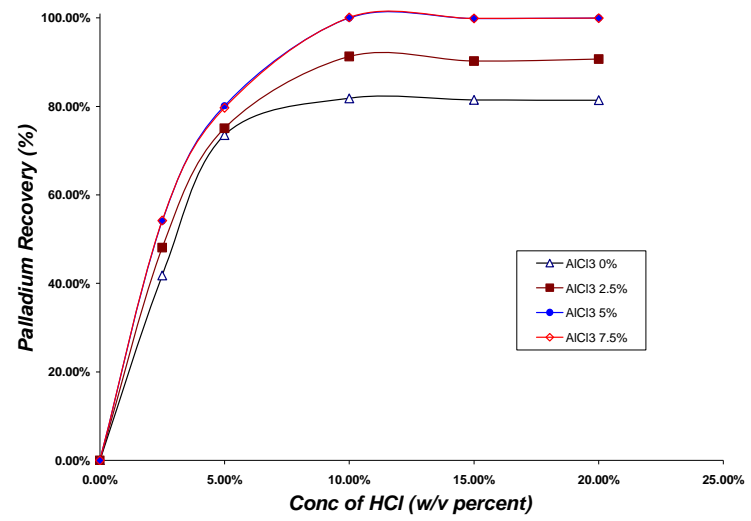

Fig. (3). The effect of the hydrochloric acid concentration on the efficiency of Pd recovery. With different concentration of $\mathrm{AlCl}_{3}$ measured after 2 hours at $80{ }^{\circ} \mathrm{C}$, with ratio $\mathrm{L} / \mathrm{S}=20$.

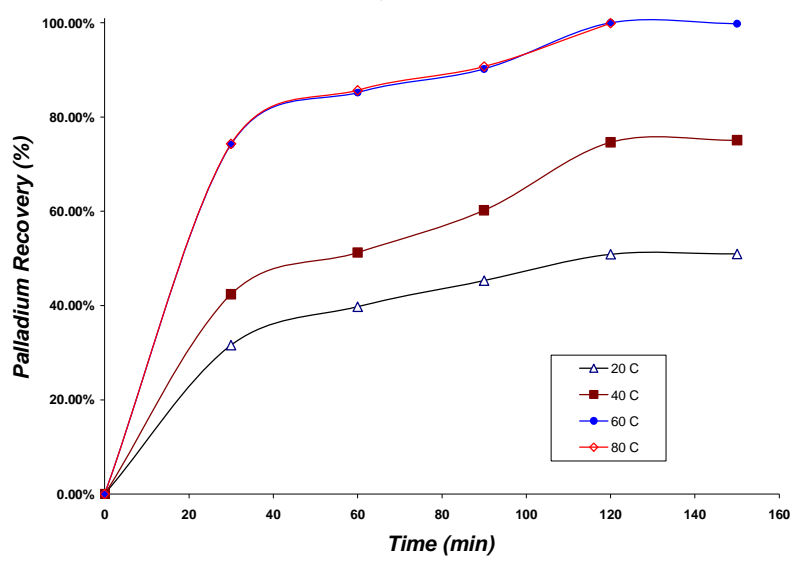

Fig. (4). The recovery of $\mathrm{Pd}$ as a function of time and temperature. With $10 \% \mathrm{HCl}, 5 \% \mathrm{AlCl}_{3}$ and $\mathrm{L} / \mathrm{S}=20$.
The dependent of the reaction rate on temperature is shown by Arrhenius equation (4) as follows;

$$
\ln \mathrm{K}=\ln \mathrm{A}-\left(\mathrm{E}_{\mathrm{a}} / \mathrm{R}\right) 1 / \mathrm{T}
$$

In this equation, $\mathrm{K}$ represents the reaction rate constant, A represents the pre-exponential factor or frequency factor, $E_{a}$ is the activation energy $(\mathrm{J} / \mathrm{mol}), T$ is the temperature (in Kelvin degrees) and $\mathrm{R}$ the universal gas constant (8.314 $\mathrm{J} / \mathrm{mol} . \mathrm{K})$ [39]. By applying this equation on the leaching process, the following graph was obtained (Fig. 5). The activation energy of the leaching reaction was calculated from the slop $\left(-E_{a} / R\right)$ to be equal to -1650.66 , resulting in a value for $\mathrm{E}_{\mathrm{a}}$ equal to $13.7 \mathrm{~K} \mathrm{~J} / \mathrm{mol}$.

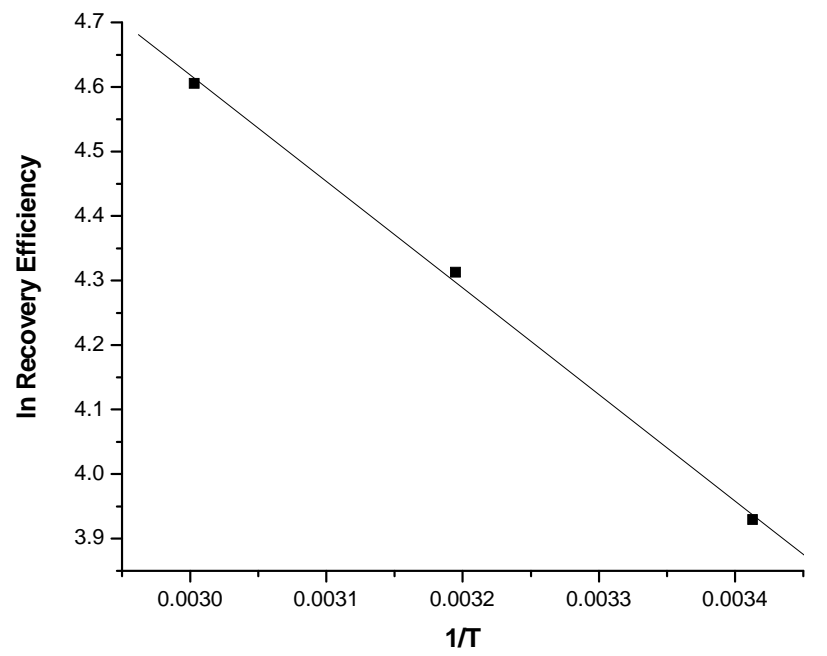

Fig. (5). The Arrhenius plot for the leaching process. $10 \% \mathrm{HCl}$, $5 \% \mathrm{AlCl}_{3}, 2$ hours and $\mathrm{L} / \mathrm{S}=20$.

\subsubsection{Effect of Liquid/Solid Ratio on Pd Recovery}

The $\mathrm{L} / \mathrm{S}$ ratio in leaching processes is an important factor from economical point of view, because it determines the reagent consumption. The effect of the $\mathrm{L} / \mathrm{S}$ ratio on leaching of Pd from the spent catalyst at $60{ }^{\circ} \mathrm{C}$ for $2 \mathrm{~h}$ was studied using leaching solution of $10 \% \mathrm{HCl}$ with $5 \% \mathrm{AlCl}_{3}$. The results are shown Fig. (6). It can be noticed that Pd recovery increased with increasing the L/S ratio, but it remained nearly constant at $\mathrm{L} / \mathrm{S}$ ratios higher than 20 , as high as 30 . It can be concluded that most of $\mathrm{Pd}$ dissolved at $\mathrm{L} / \mathrm{S}$ 
ratio of 20 , when $10 \% \mathrm{HCl}$ is used. It is obvious from the results of the studied parameters that the optimum conditions for $\mathrm{Pd}$ recovery are : leaching solutions containing $10 \% \mathrm{HCl}$ and $5 \% \mathrm{AlCl}_{3}, 2$ hours retention time, heating at $60{ }^{\circ} \mathrm{C}$ and $\mathrm{L} / \mathrm{S}$ ratio of 20 . A stock 1eacheate solution was prepared according to the optimum 1 eaching conditions that contains $0.209 \mathrm{~g} / \mathrm{L} \mathrm{Pd}$, and $5.62 \mathrm{~g} / \mathrm{L} \mathrm{Al}$. This solution was used for palladium separation experiments.

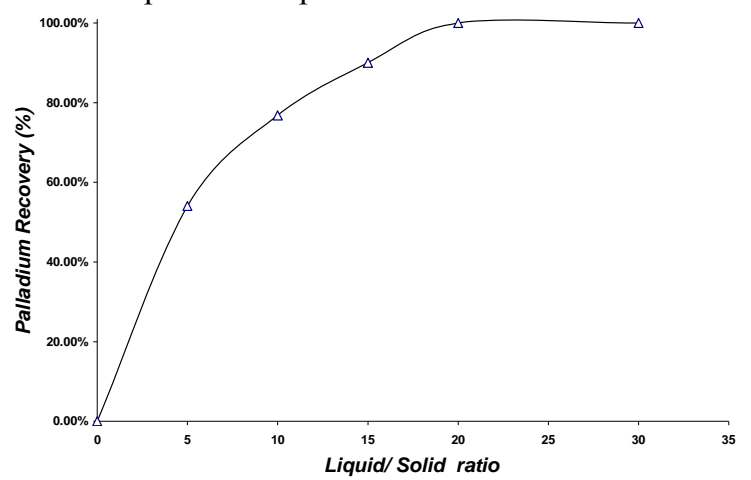

Fig. (6) The effect of liquid/ solid ratio (L/S) on Pd recovery. With $10 \% \mathrm{HCl}$ and $5 \% \mathrm{AlCl}_{3}$ at $60{ }^{\circ} \mathrm{C}$ for 2 hours.

\subsection{Electroless Deposition of Palladium}

Palladium was deposited from two individual Pd solutions, the leachate and pure solution (for comparison). The deposition process was carried out by reduction with formic acid, according to the general reaction:

$$
\mathrm{H}_{2} \mathrm{PdCl}_{4}+\mathrm{HCOOH} \stackrel{\text { Heat }}{\longrightarrow} \mathrm{Pd}_{(\mathrm{s})}+4 \mathrm{HCl}+\mathrm{CO}_{2}
$$

Two equal amounts (100 $\mathrm{ml}$ each) of the leaching palladium solution and pure palladium solution were adjusted at $\mathrm{pH}=2$ using $125 \mathrm{ml} 2 \mathrm{M} \mathrm{NaOH}$, and precipitated by $30 \mathrm{ml}$ of formic acid $85 \%$ in a closed system at $100{ }^{\circ} \mathrm{C}$ for $30 \mathrm{~min}$. After boiling a dark bright palladium was obtained. The data of the recovery efficiency for pure and waste $\mathrm{Pd}$ solution is quoted in Table $\mathbf{1}$.

\subsubsection{Characterization of the Deposited Palladium}

The deposited Pd was characterized by SEM and TEM techniques, as shown in Figs. (7 and 8). From SEM analysis, the particles appear as spherical with diameters ranged from $10 \mu \mathrm{m}$ to $1 \mu \mathrm{m}$ for $\mathrm{Pd}$ deposited from pure chemical while the diameters were smaller than $1 \mu \mathrm{m}$ for Pd deposited from waste material. TEM analysis was performed for more detailed identification of the particle size of the deposited Pd from waste material (Fig. 8). It can be seen that the particles of the deposited palladium was found to be in the nano size range ( from 34.5 to $70.5 \mathrm{~nm}$ ). This may be attributed to the fact that the $\mathrm{Pd}$ in the original sample was deposited as a thin film on the alumina carrier. The deposition of palladium by formic acid prevents the particles agglomeration and so the palladium was deposited as nanosize fines. On other hand, the EDX pattern of the Pd deposited from waste material Fig. (9), proves the purity of the deposited palladium.

\section{CONCLUSIONS}

Recycling of spent $\mathrm{Pd} / \mathrm{Al}_{2} \mathrm{O}_{3}$ catalyst for recovery of nano-palladium has been investigated. Complete dissolution of palladium was achieved by leaching with a solution containing $10 \% \mathrm{HCl}$ and $5 \% \mathrm{AlCl}_{3}$ at $60{ }^{\circ} \mathrm{C}$ for $2 \mathrm{~h}$ with a liquid/solid ratio of 20. $\mathrm{Pd}$ was deposited from two individual Pd solutions, the leachate and pure solution, by adding formic acid. The recovery efficiency of Pd from leachate of the spent catalyst was $92.3 \%$ with $98.4 \%$ purity. From

Table 1. Recovery Efficiency and Purity of the Electroless Deposited Palladium

\begin{tabular}{|c|c|c|}
\hline Parameters & Pd from Pure Chemical & Pd from Waste Material \\
\hline \hline Recovery Efficiency & $98 \%$ & $92.3 \%$ \\
\hline Purity & $99.92 \%$ & $98.4 \%$ \\
\hline
\end{tabular}

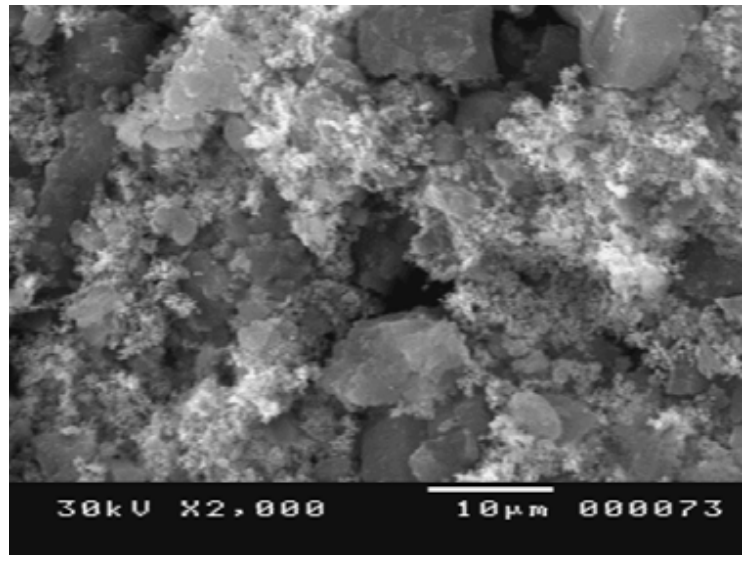

a) Pd from pure chemical

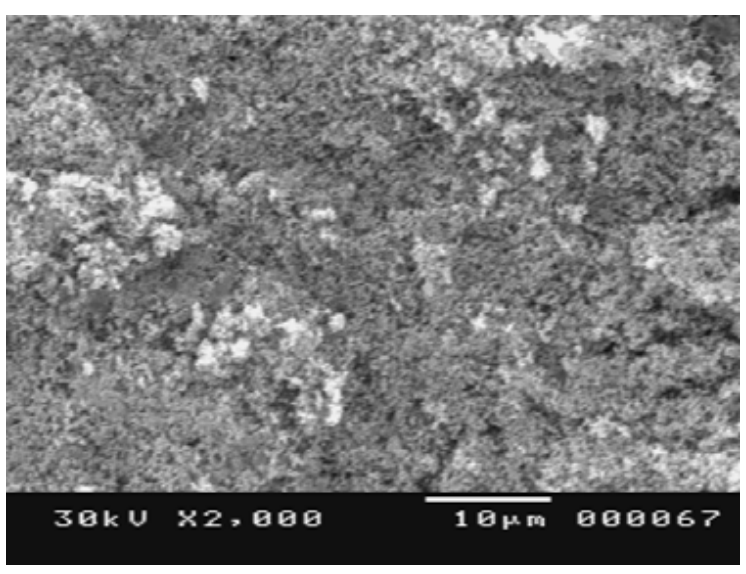

b) Pd from waste material

Fig. (7). The SEM pattern of the electroless palladium deposits. 
TEM analysis, the deposited palladium was found to be in the nanosize range $(34.5-70.5 \mathrm{~nm})$. On the other hand, Pd was deposited from pure solution with recovery efficiency of $98 \%$, and purity of $99.92 \%$. SEM analysis showed that its particle size is ranged from $(10 \mu \mathrm{m}$ to $1 \mu \mathrm{m})$.

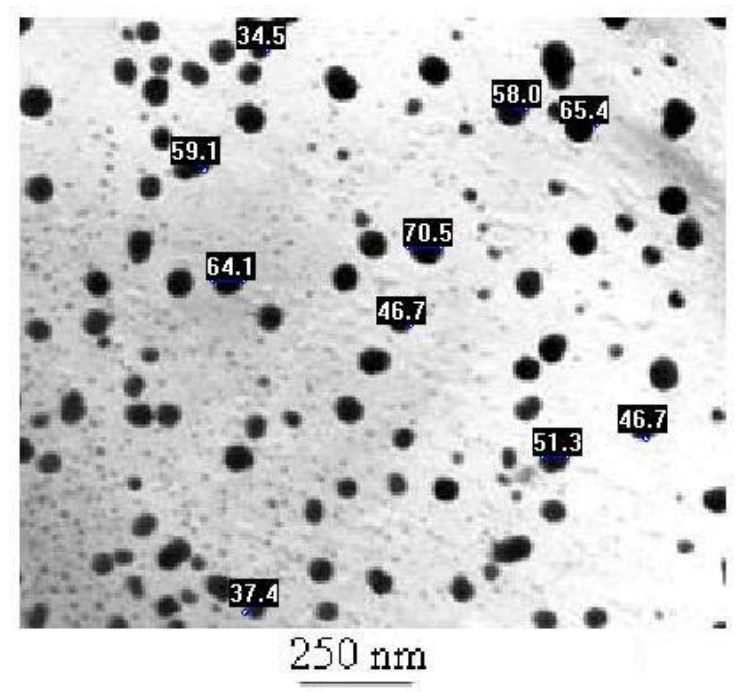

Fig. (8). The TEM pattern for electroless deposited Pd from waste solution. $60 \mathrm{KV}$ and 40000 magnification power.

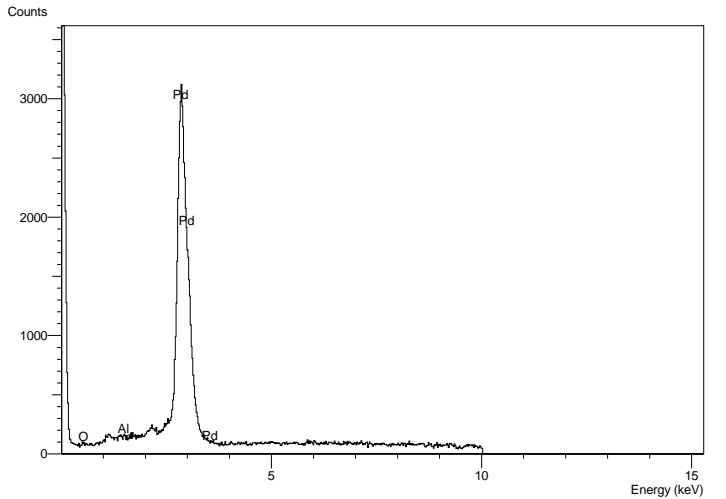

Fig. (9). EDX analysis for electroless deposited Pd from waste solution.

\section{REFERENCES}

[1] G.A. Somorjai, Surface Chemistry and Catalysis, Wiley \& Sons Inc, New York, 1994.

[2] J.A. Rodriguez, "Physical and chemical properties of bimetallic surfaces", Surface Science Reports, vol. 24, pp. 223-287, 1996.

[3] A. Cowley, M. Steel, Platinum Today, Johnson Matthey Reports, London, 2007.

[4] S. Ye and K. Uosaki, Encyclopedia of Electrochemistry. In: A.J. Bard, E. Gileadi and M. Urbakh, Eds., Thermodynamics and Electrified Interfaces 1, Wiley-VCH, Weinheim, 2002.

[5] M. Schlesinger; M. Paunovic, Modern Electroplating, $4^{\text {th }}$ ed., John Wiley Sons Inc, New York, 2000.

[6] D.V. Chavan, P.M. Dhadke, "Extraction separation of platinum (IV), and palladium (II) with CYANEX 923 in chloride media - a possible recovery from spent autocatalysts", Journal of Scientific and Industrial Research, vol. 62, pp. 834-837, 2003.

[7] H. Meyer, U. Blankenstein, J.P. Rosso, "Precious metals recovery", Petroleum Technology Quarterly, vol. 11, pp. 25-27, 2006.

[8] A.A. Mhaske, P.M. Dahadke, "Extraction separation studies of $\mathrm{Rh}, \mathrm{Pt}$ and Pd using Cyanex 921 in toluene-a possible application to recovery from spent catalysts", Hydrometallurgy, vol. 61, pp. 143-150, 2001.
S. Iwao, S.A. El-Fatah, K. Furukawa, T. Seki, M. Sasaki, M. Goto, "Recovery of palladium from spent catalyst with supercritical $\mathrm{CO}_{2}$ and chelating agent", Journal of Supercritical Fluids, vol. 42, pp. 200-204, 2007

[10] O.G. Gromov, G.N. Kunshina, A.P. Kuz'min, E.B. Seitenova, E.P. Lokshin, V.T. Kalinnikov, "Recovery of platinum and palladium from deactivated catalysts", Russian Journal of Applied Chemistry, vol. 72, pp. 1865-1868, 1999.

[11] M.A. Barakat, M.H.H. Mahmoud, Y.S. Mahrous, "Recovery and separation of palladium from spent catalyst", Applied Catalysis A: General, vol. 301, pp. 182-186, 2006.

[12] R. Noyes, Pollution Prevention Technology Handbook, Noyes Publications, Park Ridge, N.J., 1993.

[13] R.G. Schulze, Platinum Today, Johnson Matthey Reports, London, 1984.

[14] A. Gary, K. Robert, D. Desmond, US Patent, 5,160,711, 1992.

[15] D.C. Duyvesteyn, Willem, US Patent, 845,068,1994.

[16] P.L. Sibrell and G.B. Atkinson In: P.B. Queneau, Editor, Proceedings of the 3rd International Symposium on Recycling of Metals and Engineering Materials, TMS, 1995.

[17] X. Xie, X. Meng, K.N. Han, Leaching behavior of palladium in thiourea/acid solutions, Minerals and Metallurgical Processing, vol.13, pp. 119-123, 1996.

[18] S. Masahito and N. Plant, JETI vol. 46 (5) p. 56, 1998.

[19] L.J. Marc, Patent W02002053788, 2002.

[20] Z. Jun, R. Hongjiu, J. Youse Jinshu Yelian, vol. 02, p. 31, 1996.

[21] T. Nobuo, A. Satoshi, Japanese Patent, JP 9563473, 1996.

[22] V.V. Patrushev, "Reduction of platinum group metals in phosphoric acid solutions by formalin", Hydrometallurgy, vol. 50, pp. 89101, 1998.

[23] H. Suehide, K. Koji, European Patent, 114118,1998

[24] P. Yong, M. Paterson, Process Metallurgy., vol. 11B, pp. 327, 2001.

[25] P. Yong, A. Rowson, J.P.G. Farr, I.R. Harris, "Macaskie, Bioreduction and biocrystallization of palladium by Desulfovibrio desulfuricans NCIMB 8307", Biotechnolgy and Bioengineering, vol. 80, pp 369-379, 2002.

[26] M.Volpe, R.Inguanta, S.Piazza, C.Sunseri, "Developing a procedure to optimize electroless deposition of thin palladium layer on anodic alumina membranes", Desalination, vol. 199, pp. 352-354, 2006.

[27] Z. Shi, S.Wu, J.A. Szpunar, "Microstructure transformation of Pd membrane deposited on a porous Inconel substrate in hydrogen permeation at elevated temperature", Journal of Membrane Science, vol. 284, pp. 424-430, 2006.

[28] L. Chen, C. Wan and Y. Wang, "Chemical preparation of Pd nanoparticles in room temperature ethylene glycol system and its application to electroless copper deposition", Journal of Colloid and Interface Science, vol. 297, pp. 143-150, 2006.

[29] K. Kim, M. Kim and S. M. Cho, "Pulsed electrodeposition of palladium nanowire arrays using AAO template", Materials Chemistry and Physics, vol. 96, pp. 278-282, 2006.

[30] T. Ya. Safonova, D.R. Khairullin, G.A. Tsirlina, O.A. Petrii and S.Yu. "Vassiliev Palladium-polyethylene glycol quasitemplate electroplates: The effect of polymer molecular weight", Electrochimica Acta, vol. 50, pp. 4752-4762, 2005.

[31] R. Hoyer, L. A. Kibler and D. M. Kolb, "The initial stages of palladium deposition onto Pt(1 11 l $)$ ", Electrochimica Acta, vol. 49, pp. 63-72, 2003.

[32] M. E. Quayum, Shen Ye and Kohei Uosaki, "Mechanism for nucleation and growth of electrochemical palladium deposition on an $\mathrm{Au}(111)$ electrode", Journal of Electroanalytical Chemistry, vol. 520, pp. 126-132, 2002.

[33] S. Guerin and G. S. Attard, "Electrochemical behaviour of electrodeposited nanostructured palladium+platinum films in $2 \mathrm{M}$ $\mathrm{H}_{2} \mathrm{SO}_{4} "$, Electrochemistry Communications, vol. 3, pp. 544-548, 2001.

[34] M.Platt, R. A.W. Dryfe and E. P. L. Roberts, "Electrodeposition of palladium nanoparticles at the liquid-liquid interface using porous alumina templates", Electrochimica Acta, vol. 48, pp. 3037-3046, 2003. 
[35] M. Pourbaix, Atlas of Electrochemical Equilibrium in Aqueous Solutions, 1st English ed., Pergamon Press, New York, 1966, pp. 357-377.

[36] A.J. Bard, R. Parsons, Standard Potentials in Aqueous Solutions, Marcel Dekker Inc, New York, 1985.

[37] T. Fuchigami, Handbook of Electrochemistry, $5^{\text {th }}$ ed. aruzen, Tokyo 2001.
[38] S. Szabó, F. Nagy, J. Gyimesi, "The determination of dispersity and metal content of supported palladium catalysts with redox titration" Applied Catalysis A: General, vol. 238, pp 273-277, 2003

[39] J.C. Kotz, P. Treichel, Chemistry and Chemical Reactivity, $6^{\text {th }}$ ed. homson Brooks/cole, CA, 2006.

Received: March 18, 2009

Revised: May 13, 2009

Accepted: May 15, 2009

(C) Barakat et al.; Licensee Bentham Open.

This is an open access article licensed under the terms of the Creative Commons Attribution Non-Commercial License

(http://creativecommons.org/licenses/by-nc/3.0/) which permits unrestricted, non-commercial use, distribution and reproduction in any medium, provided the work is properly cited. 